\title{
Heat Shock Protein 70 Participates in the Neuroprotective Response to Intracellularly Expressed $\beta$-Amyloid in Neurons
}

\author{
Jordi Magrané, ${ }^{1,2}$ Roy C. Smith, ${ }^{2}$ Kenneth Walsh, ${ }^{2}$ and Henry W. Querfurth ${ }^{1}$ \\ ${ }^{1}$ Division of Neurology, Caritas St. Elizabeth's Medical Center, Tufts University School of Medicine, Boston, Massachusetts 02135, and ${ }^{2}$ Molecular \\ Cardiology, Whitaker Cardiovascular Institute, Boston University School of Medicine, Boston, Massachusetts 02118
}

\begin{abstract}
Intracellular $\beta$-amyloid 42 (A $\beta 42)$ accumulation is increasingly recognized as an early event in the pathogenesis of Alzheimer's disease (AD). We have developed a doxycycline-inducible adenoviral-based system that directs intracellular $\mathrm{A} \beta 42$ expression and accumulation into the endoplasmic reticulum of primary neuronal cultures in a regulated manner. $A \beta 42$ exhibited a perinuclear distribution in cell bodies and an association with vesicular compartments. Virally expressed intracellular A $\beta 42$ was toxic to neuronal cultures $24 \mathrm{hr}$ after induction in a dose-dependent manner. $\mathrm{A} \beta 42$ expression prompted the rapid induction of stress-inducible Hsp70 protein in neurons, and virally mediated Hsp70 overexpression rescued neurons from the toxic effects of intracellular $A \beta$ accumulation. Together, these results implicate the cellular stress response as a possible modulator of $\mathrm{A} \beta$-induced toxicity in neuronal cultures.
\end{abstract}

Key words: Alzheimer's disease; intracellular; amyloid; adenovirus; neuronal toxicity; stress response

\section{Introduction}

The prevailing view that extracellular $\beta$-amyloid $(\mathrm{A} \beta$ ) deposition is the primary toxic insult in Alzheimer's disease (AD) is being modified by an increasing number of studies that suggest intracellular $\mathrm{A} \beta$ accumulation may play an early and important pathologic role in the development of the disease (Takahashi et al., 2002a). Although no direct evidence has been provided, it has long been speculated that intraneuronal $\mathrm{A} \beta$ accumulation causes neuronal dysfunction, synaptic and neuronal loss, and dementia in AD and related Down's syndrome (LaFerla et al., 1995; Yang et al., 1998; Gouras et al., 2000; D'Andrea et al., 2001; Gyure et al., 2001; Busciglio et al., 2002). Several reports have documented intracellular accumulation of A $\beta$ (Martin et al., 1995; Skovronsky et al., 1998; Gouras et al., 2000; Mochizuki et al., 2000; Walsh et al., 2000; Takahashi et al., 2002b). A $\beta 42$ peptide appears to be the prominent form that accumulates inside neurons in $\mathrm{AD}$ brains and in transgenic mice expressing familial AD mutations (Takahashi et al., 2002a). However, only a limited number of reports have specifically studied the intracellular effects of $A \beta 42$ peptide accumulation using either transgenic animals (LaFerla et al., 1995; Link, 1995) or non-neuronal cell lines (Johnstone et al., 1996; Querfurth et al., 2001; Suhara et al., 2003). Recently, delivery of $A \beta$ synthetic peptides into neurons by microinjection has been reported (Zhang et al., 2002). However, the lack of methods

Received Sept. 23, 2003; revised Dec. 31, 2003; accepted Dec. 31, 2003.

This work was supported by National Institutes of Health Grants NS41371 (H.W.Q.) and AG17241, AG15052, and HL66597 (K.W.). We thank K. M. Rosen for many helpful discussions and review of this work, Mark Chafel (Optical Imaging Unit at Center for Brain Imaging, Harvard (enter for Neurodegeneration and Repair) for confocal microscope assistance, and M. H. Ericsson (Harvard Medical School Electron Microscopy Facility) for immunogold electron microscopy preparation.

Correspondence should be addressed to Henry W. Querfurth, Caritas St. Elizabeth's Medical Center, Division of Neurology, 736 Cambridge Street, Boston, MA 02135. E-mail: hquerfur@opal.tufts.edu.

DOI:10.1523/JNEUROSCI.4330-03.2004

Copyright $\odot 2004$ Society for Neuroscience $\quad 0270-6474 / 04 / 241700-07 \$ 15.00 / 0$ allowing the facile transfection of postmitotic cells has hindered the study of mechanisms of intracellular $\mathrm{A} \beta$ toxicity in primary neuronal cultures and its role in AD.

Increasing evidence points to a role for molecular chaperones in neurodegenerative diseases (DeArmond and Prusiner, 1995; Bonini, 2002; Sakahira et al., 2002). Recent findings that heat shock proteins (Hsps) can suppress neurotoxicity in animal models of Parkinson's and polyglutamine diseases (Warrick et al., 1999; Chan et al., 2000; Fernandez-Funez et al., 2000; KazemiEsfarjani and Benzer, 2000; Cummings et al., 2001; Auluck et al., 2002) suggests potential therapeutic approaches in neurodegeneration associated with abnormal protein folding and toxicity. Whereas Hsp70 and Hsp90 have been implicated in maintaining tau solubility and suppressing tau aggregates (Dou et al., 2003), the involvement of Hsp in $A \beta$-mediated toxicity has not been evaluated.

In the current study we use primary neuronal cultures and an inducible adenoviral vector system to study the effects of intracellular A $\beta 42$ accumulation. These data suggest that the cellular stress response is an important modulator of intracellular $A \beta$ toxicity in neurons.

\section{Materials and Methods}

Antibodies. The following antibodies were used: 6E10 (1:300; Signet Laboratories, Dedham, MA), anti- $\beta$-galactosidase (1:500; Promega, Madison, WI), anti-calnexin (1:200; Stressgen Biotechnologies, San Diego, CA), anti-Hsp70 (1:100-5000; Stressgen Biotechnologies), anti-Hsc70 (1:5000; Stressgen Biotechnologies), anti- $\beta$ III isoform of tubulin (1:100; Chemicon International, Temecula, CA). Secondary antibodies were used as follows: fluorescent $\mathrm{Cy} 2$ and Cy3-conjugated (Jackson ImmunoResearch, West Grove, PA), peroxidase-conjugated (Promega), alkaline phosphatase-conjugated (Dako, Santa Barbara, CA).

Adenoviral vector construction. Recombinant, E1-deleted replicationdefective adenoviral constructs were produced by standard techniques (Graham and Prevec, 1995). In brief, the human A $\beta 42$ peptide sequence 
containing an endoplasmic reticulum signal peptide based on the $\beta$ APP751 coding sequence was PCR-amplified from pHSVPrpUC-A $\beta 42$ vector (provided by Dr. R. Neve, McLean Hospital, Belmont, MA) and inserted into HindIII-XhoI sites downstream of the tetracycline response element (TRE) promoter in the plasmid pTRE (Clontech, Palo Alto, CA). To produce a reverse $\mathrm{A} \beta 42 \mathrm{cDNA}$ construct, the same sequence was amplified, but restriction sites were inverted in the generation of the PCR fragment (XhoI-HindIII). The TRE cassette was then subcloned into the multiple cloning site of pShuttle vector, and recombination with pAdEasy-1 vector was achieved following manufacturer's instructions (Quantum Biotechnologies, Montreal, Quebec, Canada). The AdTet-On and AdTRE-LacZ viruses were previously described (Mano et al., 2000). The cDNA of human $\beta$ APP751 was digested from NSE-hAPP751 vector (provided by Dr. C. R. Abraham, Boston University, Boston, MA), and inserted into the HindIII site in the plasmid pAdTrack-CMV (Clontech), followed by recombination with pAdEasy-1, as described above. AdHsp70 was provided by Dr. W. H. Dillmann (University of California, San Diego, CA). All viruses were grown to high titer in human embryonic kidney 293 cells and purified by cesium chloride density gradient ultracentrifugation. Viral titer was determined by plaque assay.

Rat primary cortical cultures. Cortices were dissected from neonatal day 1 rat Sprague Dawley brains (Charles River Laboratories, Wilmington, MA), incubated in trypsin and DNase, and then mechanically dissociated in PBSglucose solution. Neurons were plated into poly-D-lysine ( $10 \mu \mathrm{g} / \mathrm{ml}$; Sigma, St. Louis, MO) and laminin (5 $\mu \mathrm{g} / \mathrm{ml}$; Invitrogen, Carlsbad, CA)-coated plates. Mixed cultures were maintained in Neurobasal medium supplemented with B27, $0.5 \mathrm{~mm}$ glutamine, $1 \%$ penicillin-streptomycin, $4.6 \mathrm{~mm}$ $\mathrm{NaHCO}_{3}, 33 \mathrm{~mm}$ glucose, and 1\% horse serum (Invitrogen, Gaithersburg, $\mathrm{MD}$ ). Primary cortical cultures were infected $7 \mathrm{~d}$ after plating at multiplicities of infection (moi) ranging from 50 to 100. Unless indicated, AdTet-On and AdTRE-LacZ or AdTRE-A $\beta 42$ were added into culture for $18 \mathrm{hr}$ at a 1:1 ratio, and transgene expression was induced by $1 \mu \mathrm{g} / \mathrm{ml}$ doxycycline (Dox; Sigma) for $24 \mathrm{hr}$.

Western blot analysis. Cells were washed once in PBS and either scraped directly into sample buffer solution and electrophoresed in $4-12 \%$ BisTris gels (Invitrogen, Carlsbad, CA) or harvested in RIPA buffer $(50 \mathrm{~mm}$ Tris- $\mathrm{HCl}$, pH 7.4, 150 mm NaCl, 1 mm EDTA, 0.25\% Na-deoxycholate, and $1 \%$ NP-40) containing protease inhibitor cocktail (Roche Biochemicals, Indianapolis, IN), $1 \mathrm{~mm}$ sodium vanadate, and $1 \mathrm{~mm}$ sodium fluoride. Protein concentration was measured with the bicinchoninic acid (BCA) protein assay reagent (Pierce, Rockford, IL) protocol, and samples were electrophoresed in 7.5\% SDS-PAGE gels under reducing conditions. Proteins were transferred onto polyvinylidine difluoride membranes (Millipore, Billerica, MA) and immunoblotted for the indicated proteins as previously described (Magrane et al., 1999). The immunoreaction was visualized by a chemiluminescence system (Amersham Biosciences, Piscataway, NJ). Neither radiolabeling nor immunoprecipitation were required to detect $\mathrm{A} \beta 42$ peptide.

Immunocytochemistry and immunogold electron microscopy. Cells were grown on coated coverslips, washed once in PBS, and fixed in $4 \%$ paraformaldehyde. For intracellular immunodetection, cells were permeabilized with $0.1 \%$ Triton $\mathrm{X}-100$ and then incubated at $37^{\circ} \mathrm{C}$ for $45 \mathrm{~min}$ with the indicated antibodies. Cell preparations were processed for alkaline phosphatase staining or immunofluorescence as described (Magrane et al., 1999) with conjugated secondary antibodies. For TUNEL staining, the in situ cell death detection kit (Roche) was used according to manufacturer's instructions. The percentage of TUNEL-positive cells and pyknotic nuclei were obtained by counting 20 random fields per sample at $20 \mathrm{X}$ in each of four different experiments. Nikon Eclipse TE300 and Zeiss LSM 510 laser-scanning confocal microscopes were used. To prepare ultrathin frozen sections, neurons were trypsinized from the dish, fixed with $4 \%$ paraformaldehyde, and cryoprotected in $2.3 \mathrm{~m}$ sucrose. Ultrathin sections were obtained and processed for immunogold electron microscopy (Griffiths, 1993). Antibodies against $\mathrm{A} \beta$ and $10 \mathrm{~nm}$ gold-conjugated protein- $A$ (JanSlot, Utrecht, The Netherlands) were used to immunostain sections on carbon-coated hydrophilic grids. Samples were then negatively stained with uranyl acetate and examined on a JEOL1200EX transmission electron microscope (JEOL USA, Peabody, MA).

Statistical analysis. Results are expressed as the mean \pm SE. Statistical significance was determined by the Student's two-tailed, unpaired $t$ test, and a $P$ value of $<0.05$ was considered significant.

\section{Results \\ Intracellular inducible $\mathrm{A} \beta 42$ expression in primary neuronal cultures}

We constructed an adenoviral system for inducible A $\beta 42$ expression in neurons using the tetracycline-regulatable Tet-On gene expression system (Gossen et al., 1995). This system uses a coinfection strategy in which one virus (AdTet-On) provides the transactivator, while the other (AdTRE-cDNA) contains a TRE promoter that controls the expression of the transgene. Transcription of $\beta$-galactosidase or $A \beta 42$ from the TRE promoter is driven by the transactivator only when the tetracycline analog Dox is added. The absolute levels of gene expression are controlled by the dose of Dox that is added to the medium.

Rat primary cortical neuron cultures were established, and the adenoviral expression system was characterized using TRE-LacZ and TRE-A $\beta 42$ viruses. Levels of $\beta$-galactosidase or $A \beta 42$ expression, detected by immunocytochemistry, could be regulated by either varying the number of viral particles used (data not shown) or the amount of Dox added into the medium (Fig. 1a). Highefficiency transduction $(>70 \%)$ was obtained at 50 moi. The A $\beta 42$ construct was engineered with an $\mathrm{N}$-terminal signal peptide sequence to express the transgene product in the secretory pathway and, thus, mimic the in vivo sites of $\mathrm{A} \beta$ production (Takahashi et al., 2002a). The LacZ construct contained no signal peptide. Whereas $\beta$-galactosidase immunostaining was typically cytoplasmic, we observed a perinuclear distribution of A $\beta 42$ immunoreactivity and colocalization with calnexin, consistent with routing of $\mathrm{A} \beta$ to the endoplasmic reticulum (Fig. 1b,c). A $\beta 42$ expression was observed both in cell bodies and in neuritic processes (Fig. 1b). To further characterize the regulatable properties of this expression system, we performed Western blot analyses on cultures infected with a fixed amount of viral particles (100 moi of AdTet-On and AdTRE-A $\beta 42$, at a 1:5 ratio) and tested $\mathrm{A} \beta 42$ expression in response to increasing amounts of Dox $(0.3,0.5$, and $1 \mu \mathrm{g} / \mathrm{ml}$ ) for $24 \mathrm{hr}$. We detected a $4-8 \mathrm{kDa}$ band only when Dox was present in the culture media, and levels of $\mathrm{A} \beta$ peptide increased with higher doses of Dox (Fig. 1d, top and middle panels). A $\beta 42$ accumulation was detected $6 \mathrm{hr}$ after Dox induction (Fig. $1 d$, bottom panel). A $\beta 42$ was not detected in the media by ELISA or Western blot techniques in infected cells at any dose of Dox or using higher moi (data not shown). These results demonstrate that this vector system produces regulatable levels of intracellular $\mathrm{A} \beta$ expression.

We performed immunogold electron microscopy to determine the subcellular localization of inducible $A \beta 42$ transgene product in the neuronal cultures. $\mathrm{A} \beta 42$ appeared to be associated with membrane compartments, mainly the endoplasmic reticulum and associated vesicles (Fig. 2, top panel). A $\beta 42$ was found in both small vesicles ( $\sim 45 \%$ of identifiable labeling), confined mostly located to the membrane, and in multivesicular bodies ( $\sim 35 \%$ ) (Fig. 2, bottom right panel). Gold particles were present individually or in small groups, but no $\mathrm{A} \beta$ fibrils were detected. Non-induced neurons were used as negative controls and confirmed the lack of immunoreactivity (Fig. 2, bottom left panel).

\section{Intracellular expression of $\mathrm{A} \boldsymbol{\beta}$ is toxic to neurons}

To study the effects of intracellular $A \beta$ expression on primary neuronal culture viability, transgene expression was induced for $24 \mathrm{hr}$, and cultures were analyzed for the presence of pyknotic nuclei and TUNEL-positive cells as indicators of apoptosis. Ex- 
pression of a reverse $\mathrm{A} \beta 42 \mathrm{cDNA}$ or $\beta$-galactosidase transgene did not result in significant toxicity at 100 moi, whereas A $\beta 42$ expression increased the number of both pyknotic nuclei and TUNEL-positive cells (Fig. 3a,b). In contrast, virally overexpressed $\beta$ APP751 had no effect on cell death $24 \mathrm{hr}$ after infection (Fig. 3b). Most of the cells with signs of apoptosis appeared to be neurons. To confirm preferential neuronal vulnerability, we established neuron-enriched cultures ( $>95 \%$ neurons) and observed the same effect when $\mathrm{A} \beta 42$ was induced (Fig. $3 b$, inset). $\mathrm{A} \beta$-induced neuron death could be modulated either by varying the number of viral particles (0-100 moi) or the amount of Dox $(0-1 \mu \mathrm{g} / \mathrm{ml}$, at $50 \mathrm{moi})$. Thus, a direct correlation was observed between the number of apoptotic cells and the production of the $A \beta 42$ transgene product (Fig. $3 c, d)$. This increase in cell death was not observed in TRELacZ controls (Fig. $3 a-d$ ).

\section{Intracellular $\mathrm{A} \boldsymbol{\beta}$ affects the neuronal stress response}

Having demonstrated the toxic effects of intracellular $\mathrm{A} \beta 42$ accumulation, we analyzed the role of the stress response in these neuronal cultures. The expression of two Hsp family members, Hsp70 and Hsc70, was assessed in cells infected with 50 moi of AdTet-On and AdTRE-transgene (1:5 ratio). $\mathrm{A} \beta 42$ expression increased the Hsp70 stress-inducible form as early as 6 $\mathrm{hr}$, and maximal induction was reached by $24 \mathrm{hr}$. Expression of $\beta$-galactosidase in parallel cultures had no effect on Hsp70 expression. Levels of the constitutively expressed form of Hsp70, Hsc 70, did not change at any time point, and similar total protein levels of the $\beta$-III isoform of tubulin were detected among all lanes (Fig. 4a,b). In contrast, virally overexpressed $\beta$ APP751 had no effect on Hsp70 protein levels (data not shown). We performed immunofluorescence in rat cortical cultures to confirm the upregulation of Hsp70. A $\beta 42$-positive cells showed increased Hsp70 expression, whereas $\beta$-galactosidase-expressing cells did not (Fig. $4 c, e$ ). Only cells with neuronal morphologies were affected by the stress response (Fig. $4 c, e$ ).

\section{Hsp70 protects against intracellular $\mathrm{A} \boldsymbol{\beta}$-induced toxicity}

To address whether the increase in Hsp70 expression in response to $\mathrm{A} \beta 42$ accumulation could be a cellular mechanism to protect against $\mathrm{A} \beta$ toxicity, cultures were co-transduced with an adenoviral vector expressing Hsp70. Primary neuronal cultures were infected at 100 moi for $18 \mathrm{hr}$, after which Dox and 10 moi of AdHsp70 virus or AdLacZ control virus were added for $24 \mathrm{hr}$. Strikingly, overexpression of Hsp70 (Fig. 5b, inset) protected against the toxic effects of $A \beta 42$ accumulation, as shown by significant reductions in the number of both pyknotic nuclei and TUNEL-positive cells in A $\beta 42$-expressing cultures. Overexpression of $\beta$-galactosidase had no effect on $A \beta 42$ neurotoxicity (Fig. $5)$. The expression levels of $A \beta 42$ were unaltered by co-infection
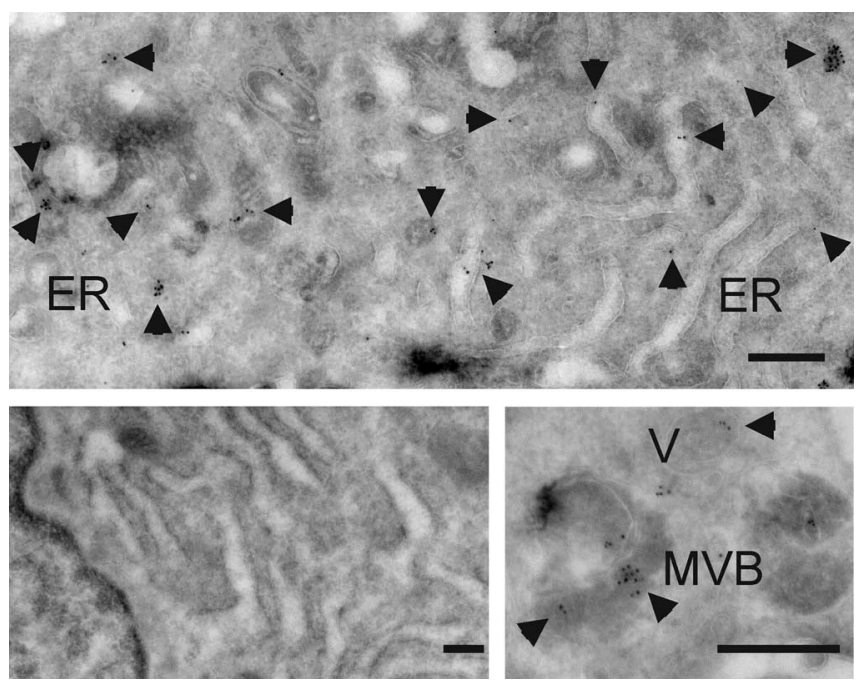

Figure 2. $\quad A \beta 42$ expression within the endoplasmic reticulum and in association with vesicular membranes. Immunogold localization of $A \beta 42$ (arrowheads) using $6 \mathrm{E} 10$ antibody in neuronal cultures (top). Lack of immunogold labeling in non-induced controls (bottom left). A $\beta 42$ immunogold particles with small vesicles and multivesicular bodies (bottom right). ER, Endoplasmic reticulum; V, vesicle; MVB, multivesicular body. Scale bars, $200 \mathrm{~nm}$. 
a
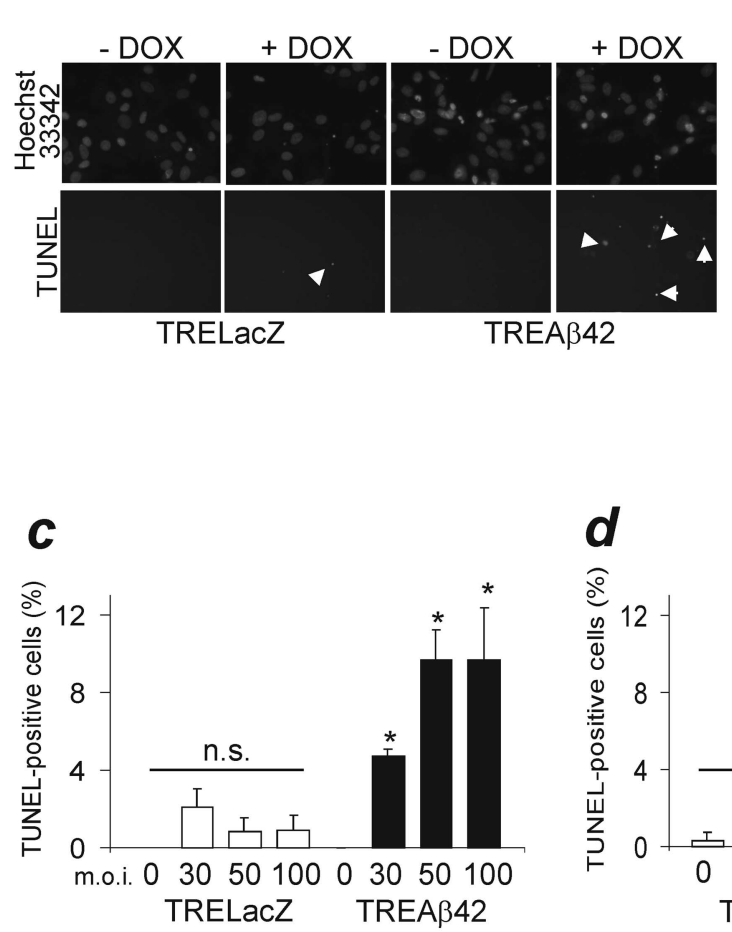

Figure 3. Intracellular $A \beta 42$ expression results in apoptosis in primary neuronal cultures. $a$, Nuclear pyknosis (Hoescht 33342 staining) and TUNEL staining in infected neuronal cultures. LaCZ expression and non-induced controls produced similar background levels. $b$, Quantification of data from four independent experiments is shown. Comparison of induced transgene products, ${ }^{*} p<0.005$. Inset, $A \beta 42$ toxicity in neuron-enriched cultures (TUNEL staining), $p<0.001 . c, d$, The extent of $A \beta 42$ toxicity could be adjusted by varying either the number of viral particles or the amount of $\operatorname{Dox}(n=4)$. Values are subtracted in each experiment with their control (basal) conditions. ${ }^{*} p<0.005 ;{ }^{* *} p<0.05$; n.S., non-significant.

with either AdHsp70 or AdLacZ (Fig. 5c). These data implicate the stress response in a possible role for overcoming $\mathrm{A} \beta$-induced toxicity in neuronal cultures.

\section{Discussion}

An increasing number of reports suggest that $A \beta 42$ accumulates inside neurons with aging and that intraneuronal $\mathrm{A} \beta$ may be a seminal event in the neuronal and synaptic degeneration that is characteristic of AD. Some approaches have been developed (LaFerla et al., 1995; Zhang et al., 2002); however, there is no facile method to date for the intracellular expression of $A \beta 42$ in postmitotic cells and thus, the intracellular effects of $A \beta$ accumulation in neurons have not been fully characterized. Here we describe an inducible viral gene expression system that allows efficient transduction of neurons and provides regulated intracellular expression of the A $\beta 42$ peptide (Harding et al., 1997). Intracellular $A \beta 42$ expression was toxic to neuron cultures from rat cortex, and different $\mathrm{A} \beta$ expression levels correlated with levels of toxicity. This toxicity was not associated with peptide secretion into the medium. These data support the hypothesis that neuronal apoptosis in $\mathrm{AD}$ and Down's syndrome is associated with intracellular $A \beta$ deposition (Cotman, 1998). Further support is provided by the finding that apoptosis in neurons is indirectly correlated with intracellular $A \beta$ accumulation produced after long-term expression of APP695 (Nishimura et al., 1998; Kienlen-Campard et al., 2002). The recent studies of Oddo et al. (2003) lend strong credence to the notion that synaptic dysfunc- tion correlates with early accumulation of intracellular $\beta$-amyloid.

In $\mathrm{AD}$, as in other neurodegenerative diseases, selected cell types and populations are preferentially affected by the accumulation of a toxic product. We observed efficient transduction of both neurons and glial cells in mixed rat cultures, yet neurons appeared to be mainly affected by the virally mediated intracellular $A \beta 42$ expression. Stress responses are also cell type-specific. The observed A $\beta 42$ effect on Hsp70 expression levels in neurons but not in glia seems to be $\mathrm{A} \beta$ specific, because in other stress situations Hsp70 is weakly induced in nerve cells and highly upregulated in glial cells (Nishimura et al., 1991; Satoh and Kim, 1994). Interestingly, the rapid upregulation of Hsp70, as early as $6 \mathrm{hr}$, corresponded to detectable but low levels of $\mathrm{A} \beta$ at this time point. Transduction with Hsp70 reduced A $\beta 42$-induced toxicity, suggesting that the endogenous stress response in neurons was insufficiently protective against $\mathrm{A} \beta$.

Immunofluorescence and ultrastructural studies confirmed $\mathrm{A} \beta 42$ localization in the endoplasmic reticulum (Hartmann et al., 1997) and in small vesicles and multivesicular bodies (Takahashi et al., 2002b). Approximately $40-60 \%$ of vesicular-associated immunogold labeling was found located on the membrane. No intracellular aggregates of $\mathrm{A} \beta 42$ were observed by microscopy techniques, and no higher molecular weight species were detected by Western blot. Taken with results discussed above, these data suggest that soluble $A \beta$ in intracellular compartments is toxic without fibril or aggregate formation. These data are consistent with the growing evidence that toxicity may be dissociated from protein aggregate formation in some neurodegenerative diseases (Takahashi et al., 1994; Cummings et al., 1999; Walsh et al., 2000; Shimura et al., 2001; Ma and Lindquist, 2002).

Neurodegenerative diseases, such as polyglutamine disorders, Parkinson's disease, prion diseases, and AD, appear to be triggered by the progressive intracellular accumulation of specific yet unrelated toxic proteins that target select cell populations. Different mechanisms have been proposed to explain neurodegeneration, for instance the $\mathrm{p} 53$, JNK, and PI3K/Akt signaling pathways are reported to be affected by intracellular $\mathrm{A} \beta$ (LaFerla et al., 1996; Shoji et al., 2000; Zhang et al., 2002; Suhara et al., 2003). However, increasing evidence points to a role for molecular chaperones in these neurodegenerative processes (Bonini, 2002; Sakahira et al., 2002). The activation of cellular stress pathways has been demonstrated in models of polyglutamine diseases (Chai et al., 1999; Jana et al., 2000; Manning-Bog et al., 2003). However, no clear role of $\mathrm{Hsp}$ on $\mathrm{A} \beta$ pathology in $\mathrm{AD}$ has been established. Our data demonstrates an upregulation of Hsp70 in response to intraneuronal $\mathrm{A} \beta 42$ expression in a dose-dependent manner. This finding supports previous observations of increased accumulation of Hsp70 in AD brains (Hamos et al., 1991; Perez et al., 1991). Thus, we hypothesized that an imbalance be- 
a

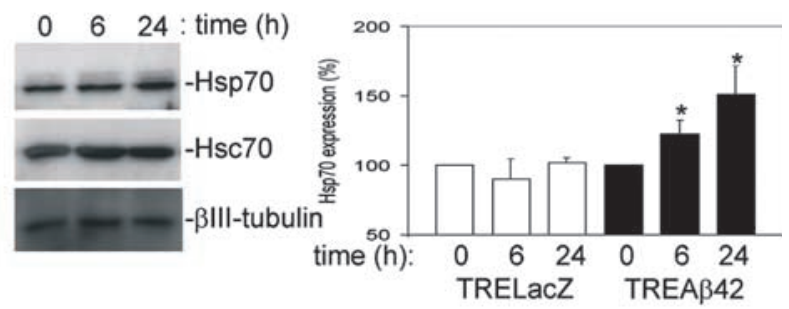

C
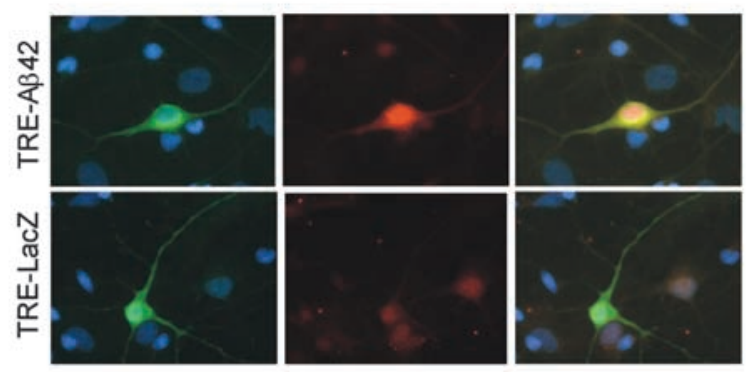

d

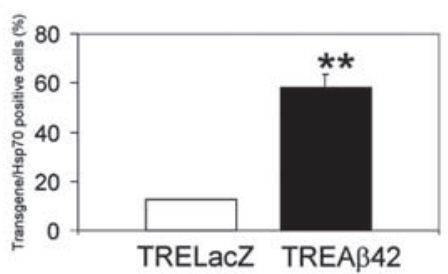

e

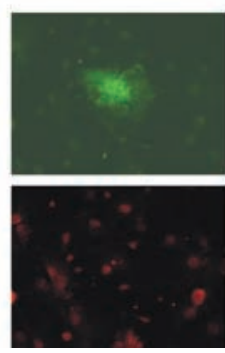

Figure 4. Intracellular $A \beta 42$ production induces a cellular stress response in primary neuronal cultures. Cultures were infected, and $A \beta 42$ expression was induced for different durations. $a$, Protein levels of two Hsp family members were assayed by Western blot. $\mathrm{Hsc70}$ and $\beta \mathrm{III-}$ tubulin levels were similar among lanes. $b$, Quantitative data on relative inducible $\mathrm{Hsp70}$ expression levels referred to $0 \mathrm{hr}$ time point $(n=3) .{ }^{*} p<0.02$. c, A $\beta 42$ overexpression (green, top panel) in neurons correlated with increased Hsp70 immunostaining (red), whereas $\beta$-galactosidase (green, bottom panel) did not. Merged images showing coincidence of staining in yellow (right). $d$, Quantitation of transgene-expressing cells that show $\mathrm{Hsp70}$ overexpres$\operatorname{sion}(n=3) .{ }^{* *} p<0.002$.e, A $\beta 42$-positive glial cells (green) did not show Hsp70 upregulation (red).

tween the neuronal Hsp capacity and the toxic accumulation of $\mathrm{A} \beta$ may be responsible for the observed neuron death.

Our studies identify the neuroprotective role of Hsp70 in a culture model of intracellular $\mathrm{A} \beta$ accumulation, and provide the first evidence for the involvement of Hsp in $\mathrm{A} \beta$-mediated toxicity in $\mathrm{AD}$. Although we have no direct evidence of a physical interaction between $\mathrm{A} \beta 42$ and $\mathrm{Hsp} 70, \mathrm{~A} \beta 42$ peptide may come in contact with $\mathrm{Hsp} 70$ if it is reverse translocated to the cytosol by the endoplasmic reticulum quality control system (McCracken and Brodsky, 2003). In support of this hypothesis, Hsp70 family members have been shown to interact with intracellular $\mathrm{A} \beta$ when expressed in the cytosolic compartment of a transgenic Caenorhabditis elegans model (Fonte et al., 2002). Because Hsp70 has roles in preventing protein aggregation and promoting protein degradation (Muchowski et al., 2000; Dul et al., 2001; Chan et al., 2002; Dou et al., 2003), it is plausible that Hsp70 is critical in the sequestration of intraneuronal $\mathrm{A} \beta$. Alternatively, Hsp70 may prevent $\mathrm{A} \beta$ from interacting with cell survival proteins (Suhara et al., 2003).

Taken together, our findings show that the stress response in

a

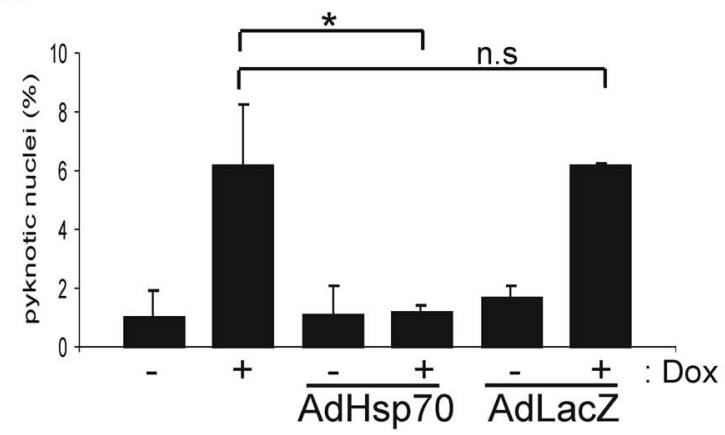

b

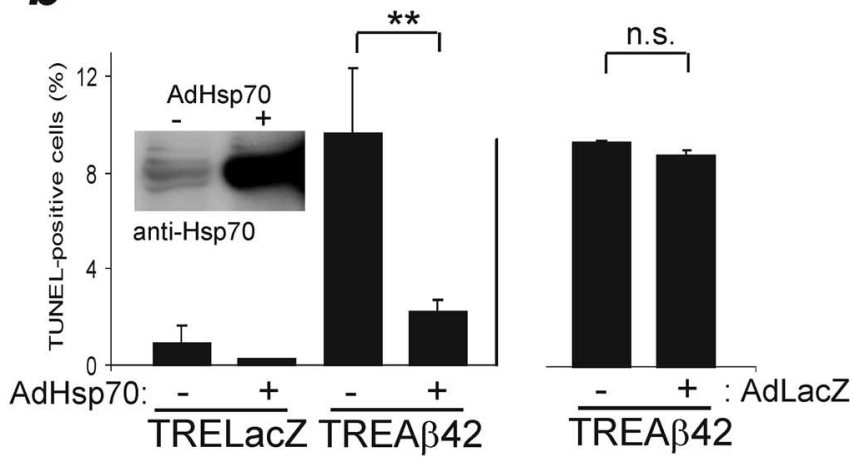

C

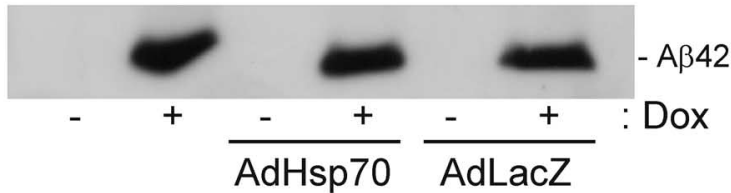

Figure 5. Hsp70 overexpression rescues $A \beta 42$-induced toxicity. $a$, Co-infection with AdHsp70 fully protected against $A \beta 42$ induced neuronal death. Co-infection with the control construct AdLacZ did not effect A $\beta 42$-induced toxicity. ${ }^{*} p<0.0005$, n.S., non-significant. $b$, The neuroprotective effect of Hsp70 overexpression (inset) was also observed by using TUNEL staining in $A \beta 42$-induced neuron cultures. Co-infection with AdLacZ had no neuroprotective effects. ${ }^{* *} p<0.005$, n.s., nonsignificant. Values from three independent experiments are shown. $C, A \beta 42$ expression levels were not affected by the overexpression of Hsp70 or $\beta$-galactosidase.

neurons is activated by intracellular $A \beta 42$ generation, suggesting that the pathogenesis of $\mathrm{AD}$ is mechanistically linked to that of other neurodegenerative disorders. Interventions that further enhance the stress response may have therapeutic value in limiting the neuronal dysfunction and loss that defines these disease states.

\section{References}

Auluck PK, Chan HY, Trojanowski JQ, Lee VM, Bonini NM (2002) Chaperone suppression of alpha-synuclein toxicity in a Drosophila model for Parkinson's disease. Science 295:865-868.

Bonini NM (2002) Chaperoning brain degeneration. Proc Natl Acad Sci USA 99 [Suppl 4]:16407-16411.

Busciglio J, Pelsman A, Wong C, Pigino G, Yuan M, Mori H, Yankner BA (2002) Altered metabolism of the amyloid beta precursor protein is associated with mitochondrial dysfunction in Down's syndrome. Neuron 33:677-688.

Chai Y, Koppenhafer SL, Bonini NM, Paulson HL (1999) Analysis of the role of heat shock protein (Hsp) molecular chaperones in polyglutamine disease. J Neurosci 19:10338-10347. 
Chan HY, Warrick JM, Gray-Board GL, Paulson HL, Bonini NM (2000) Mechanisms of chaperone suppression of polyglutamine disease: selectivity, synergy and modulation of protein solubility in Drosophila. Hum Mol Genet 9:2811-2820.

Chan HY, Warrick JM, Andriola I, Merry D, Bonini NM (2002) Genetic modulation of polyglutamine toxicity by protein conjugation pathways in Drosophila. Hum Mol Genet 11:2895-2904.

Cotman CW (1998) Apoptosis decision cascades and neuronal degeneration in Alzheimer's disease. Neurobiol Aging 19:S29-32.

Cummings CJ, Reinstein E, Sun Y, Antalffy B, Jiang Y, Ciechanover A, Orr HT, Beaudet A, Zoghbi HY (1999) Mutation of the E6-AP ubiquitin ligase reduces nuclear inclusion frequency while accelerating polyglutamine-induced pathology in SCA1 mice. Neuron 24:879-892.

Cummings CJ, Sun Y, Opal P, Antalffy B, Mestril R, Orr HT, Dillmann WH, Zoghbi HY (2001) Over-expression of inducible HSP70 chaperone suppresses neuropathology and improves motor function in SCA1 mice. Hum Mol Genet 10:1511-1518.

D'Andrea MR, Nagele RG, Wang HY, Peterson PA, Lee DH (2001) Evidence that neurones accumulating amyloid can undergo lysis to form amyloid plaques in Alzheimer's disease. Histopathology 38:120-134.

DeArmond SJ, Prusiner SB (1995) Prion protein transgenes and the neuropathology in prion diseases. Brain Pathol 5:77-89.

Dou F, Netzer WJ, Tanemura K, Li F, Hartl FU, Takashima A, Gouras GK, Greengard P, Xu H (2003) Chaperones increase association of tau protein with microtubules. Proc Natl Acad Sci USA 100:721-726.

Dul JL, Davis DP, Williamson EK, Stevens FJ, Argon Y (2001) Hsp70 and antifibrillogenic peptides promote degradation and inhibit intracellular aggregation of amyloidogenic light chains. J Cell Biol 152:705-716.

Fernandez-Funez P, Nino-Rosales ML, de Gouyon B, She WC, Luchak JM, Martinez P, Turiegano E, Benito J, Capovilla M, Skinner PJ, McCall A, Canal I, Orr HT, Zoghbi HY, Botas J (2000) Identification of genes that modify ataxin-1-induced neurodegeneration. Nature 408:101-106.

Fonte V, Kapulkin V, Taft A, Fluet A, Friedman D, Link CD (2002) Interaction of intracellular beta amyloid peptide with chaperone proteins. Proc Natl Acad Sci USA 99:9439-9444.

Gossen M, Freundlieb S, Bender G, Muller G, Hillen W, Bujard H (1995) Transcriptional activation by tetracyclines in mammalian cells. Science 268:1766-1769.

Gouras GK, Tsai J, Naslund J, Vincent B, Edgar M, Checler F, Greenfield JP, Haroutunian V, Buxbaum JD, Xu H, Greengard P, Relkin NR (2000) Intraneuronal Abeta42 accumulation in human brain. Am J Pathol 156:15-20.

Graham FL, Prevec L (1995) Methods for construction of adenovirus vectors. Mol Biotechnol 3:207-220.

Griffiths G (1993) Fine structure immunocytochemistry. Heidelberg: Springer.

Gyure KA, Durham R, Stewart WF, Smialek JE, Troncoso JC (2001) Intraneuronal abeta-amyloid precedes development of amyloid plaques in Down syndrome. Arch Pathol Lab Med 125:489-492.

Hamos JE, Oblas B, Pulaski-Salo D, Welch WJ, Bole DG, Drachman DA (1991) Expression of heat shock proteins in Alzheimer's disease. Neurology 41:345-350.

Harding TC, Geddes BJ, Noel JD, Murphy D, Uney JB (1997) Tetracyclineregulated transgene expression in hippocampal neurones following transfection with adenoviral vectors. J Neurochem 69:2620-2623.

Hartmann T, Bieger SC, Bruhl B, Tienari PJ, Ida N, Allsop D, Roberts GW, Masters CL, Dotti CG, Unsicker K, Beyreuther K (1997) Distinct sites of intracellular production for Alzheimer's disease A beta40/42 amyloid peptides. Nat Med 3:1016-1020.

Jana NR, Tanaka M, Wang G, Nukina N (2000) Polyglutamine lengthdependent interaction of Hsp40 and Hsp70 family chaperones with truncated N-terminal huntingtin: their role in suppression of aggregation and cellular toxicity. Hum Mol Genet 9:2009-2018.

Johnstone EM, Babbey LE, Stephenson D, Paul DC, Santerre RF, Clemens JA, Williams DC, Little SP (1996) Nuclear and cytoplasmic localization of the beta-amyloid peptide (1-43) in transfected 293 cells. Biochem Biophys Res Commun 220:710-718.

Kazemi-Esfarjani P, Benzer S (2000) Genetic suppression of polyglutamine toxicity in Drosophila. Science 287:1837-1840.

Kienlen-Campard P, Miolet S, Tasiaux B, Octave JN (2002) Intracellular amyloid-beta 1-42, but not extracellular soluble amyloid-beta peptides, induces neuronal apoptosis. J Biol Chem 277:15666-15670.
LaFerla FM, Tinkle BT, Bieberich CJ, Haudenschild CC, Jay G (1995) The Alzheimer's A beta peptide induces neurodegeneration and apoptotic cell death in transgenic mice. Nat Genet 9:21-30.

LaFerla FM, Hall CK, Ngo L, Jay G (1996) Extracellular deposition of betaamyloid upon p53-dependent neuronal cell death in transgenic mice. J Clin Invest 98:1626-1632.

Link CD (1995) Expression of human beta-amyloid peptide in transgenic Caenorhabditis elegans. Proc Natl Acad Sci USA 92:9368-9372.

Ma J, Lindquist S (2002) Conversion of PrP to a self-perpetuating PrPSclike conformation in the cytosol. Science 298:1785-1788.

Magrane J, Casaroli-Marano RP, Reina M, Gafvels M, Vilaro S (1999) The role of O-linked sugars in determining the very low density lipoprotein receptor stability or release from the cell. FEBS Lett 451:56-62.

Manning-Bog AB, McCormack AL, Purisai MG, Bolin LM, Di Monte DA (2003) Alpha-synuclein overexpression protects against paraquatinduced neurodegeneration. J Neurosci 23:3095-3099.

Mano T, Luo Z, Suhara T, Smith RC, Esser S, Walsh K (2000) Expression of wild-type and noncleavable Fas ligand by tetracycline-regulated adenoviral vectors to limit intimal hyperplasia in vascular lesions. Hum Gene Ther 11:1625-1635.

Martin BL, Schrader-Fischer G, Busciglio J, Duke M, Paganetti P, Yankner BA (1995) Intracellular accumulation of beta-amyloid in cells expressing the Swedish mutant amyloid precursor protein. J Biol Chem 270:26727-26730.

McCracken AA, Brodsky JL (2003) Evolving questions and paradigm shifts in endoplasmic-reticulum-associated degradation (ERAD). Bioessays 25:868-877.

Mochizuki A, Tamaoka A, Shimohata A, Komatsuzaki Y, Shoji S (2000) Abeta42-positive non-pyramidal neurons around amyloid plaques in Alzheimer's disease. Lancet 355:42-43.

Muchowski PJ, Schaffar G, Sittler A, Wanker EE, Hayer-Hartl MK, Hartl FU (2000) Hsp70 and hsp40 chaperones can inhibit self-assembly of polyglutamine proteins into amyloid-like fibrils. Proc Natl Acad Sci USA 97:7841-7846.

Nishimura I, Uetsuki T, Dani SU, Ohsawa Y, Saito I, Okamura H, Uchiyama Y, Yoshikawa K (1998) Degeneration in vivo of rat hippocampal neurons by wild-type Alzheimer amyloid precursor protein overexpressed by adenovirus-mediated gene transfer. J Neurosci 18:2387-2398.

Nishimura RN, Dwyer BE, Clegg K, Cole R, de Vellis J (1991) Comparison of the heat shock response in cultured cortical neurons and astrocytes. Brain Res Mol Brain Res 9:39-45.

Oddo S, Caccamo A, Shepherd J, Murphy MP, Golde T, Kayed R, Metherate R, Mattson MP, Akbari Y, LaFerla FM (2003) Triple transgenic model of Alzheimer's disease with plaques and tangles: intracellular $A \beta$ and synaptic dysfunction. Neuron 39:409-421.

Perez N, Sugar J, Charya S, Johnson G, Merril C, Bierer L, Perl D, Haroutunian V, Wallace W (1991) Increased synthesis and accumulation of heat shock 70 proteins in Alzheimer's disease. Brain Res Mol Brain Res 11:249-254.

Querfurth HW, Suhara T, Rosen KM, McPhie DL, Fujio Y, Tejada G, Neve RL, Adelman LS, Walsh K (2001) Beta-amyloid peptide expression is sufficient for myotube death: implications for human inclusion body myopathy. Mol Cell Neurosci 17:793-810.

Sakahira H, Breuer P, Hayer-Hartl MK, Hartl FU (2002) Molecular chaperones as modulators of polyglutamine protein aggregation and toxicity. Proc Natl Acad Sci USA 99 Suppl 4:16412-16418.

Satoh J, Kim SU (1994) HSP72 induction by heat stress in human neurons and glial cells in culture. Brain Res 653:243-250.

Shimura H, Schlossmacher M, Hattori N, Frosch M, Trockenbacher A, Schneider R, Mizuno Y, Kosik K, Selkoe DJ (2001) Ubiquitination of a novel form of $\alpha$-synuclein by parkin from human brain: implications for Parkinson's disease. Science 293:263-269.

Shoji M, Iwakami N, Takeuchi S, Waragai M, Suzuki M, Kanazawa I, Lippa CF, Ono S, Okazawa H (2000) JNK activation is associated with intracellular beta-amyloid accumulation. Brain Res Mol Brain Res 85:221-233.

Skovronsky DM, Doms RW, Lee VM (1998) Detection of a novel intraneuronal pool of insoluble amyloid beta protein that accumulates with time in culture. J Cell Biol 141:1031-1039.

Suhara T, Magrane J, Rosen K, Christensen R, Kim HS, Zheng B, McPhie DL, Walsh K, Querfurth H (2003) Abeta42 generation is toxic to endothelial 
cells and inhibits eNOS function through an Akt/GSK-3beta signalingdependent mechanism. Neurobiol Aging 24:437-451.

Takahashi H, Ohama E, Suzuki S, Horikawa Y, Ishikawa A, Morita T, Tsuji S, Ikuta F (1994) Familial juvenile parkinsonism: clinical and pathologic study in a family. Neurology 44:437-441.

Takahashi RH, Nam EE, Edgar M, Gouras GK (2002a) Alzheimer betaamyloid peptides: normal and abnormal localization. Histol Histopathol 17:239-246.

Takahashi RH, Milner TA, Li F, Nam EE, Edgar MA, Yamaguchi H, Beal MF, $\mathrm{Xu} \mathrm{H}$, Greengard P, Gouras GK (2002b) Intraneuronal Alzheimer abeta42 accumulates in multivesicular bodies and is associated with synaptic pathology. Am J Pathol 161:1869-1879.
Walsh DM, Tseng BP, Rydel RE, Podlisny MB, Selkoe DJ (2000) The oligomerization of amyloid beta-protein begins intracellularly in cells derived from human brain. Biochemistry 39:10831-10839.

Warrick JM, Chan HY, Gray-Board GL, Chai Y, Paulson HL, Bonini NM (1999) Suppression of polyglutamine-mediated neurodegeneration in Drosophila by the molecular chaperone HSP70. Nat Genet 23:425-428.

Yang AJ, Chandswangbhuvana D, Margol L, Glabe CG (1998) Loss of endosomal/lysosomal membrane impermeability is an early event in amyloid Abeta1-42 pathogenesis. J Neurosci Res 52:691-698.

Zhang Y, McLaughlin R, Goodyer C, LeBlanc A (2002) Selective cytotoxicity of intracellular amyloid beta peptide1-42 through p53 and Bax in cultured primary human neurons. J Cell Biol 156:519-529. 